the associations with joint and muscle involvement, lung fibrosis, and intestinal symptoms were confirmed (table 1).

Table 1 Results of the univariable and multivariable analysis adjusted on sex, age at disease onset and disease duration ( $n=8142$ patients). Results are presented as number/number available data (\%) unless stated otherwise.

\begin{tabular}{|c|c|c|c|c|c|c|}
\hline \multirow[b]{2}{*}{ Characteristics } & \multicolumn{3}{|c|}{ Univariable analysis } & \multicolumn{3}{|c|}{ Multivariable analysis } \\
\hline & Anti.Pm/scl- & Anti-Pm/Scl+ & $\begin{array}{c}p \\
\text { Value }\end{array}$ & $\begin{array}{l}\mathrm{N} \text { available } \\
\text { data (\%) }\end{array}$ & OR (95\% Cl) & $\begin{array}{c}p \\
\text { Value }\end{array}$ \\
\hline $\begin{array}{l}\text { Age at disease onset (vears, } \\
\text { mean (SD) (n available) }\end{array}$ & $46.7(14.5)(6885)$ & $44.7(15.1)(140)$ & 0.081 & $7025(86.3)$ & $0.98(0.90$ to 0.99$)$ & 0.0015 \\
\hline $\begin{array}{l}\text { Disease duration (months, } \\
\text { mean (SO) (n available) }\end{array}$ & $152.2(107.6)(6874)$ & 129.5 (99.6) (139) & 0.052 & $7013(86.1)$ & $\begin{array}{c}0.997(0.995 \text { to } \\
0.999)\end{array}$ & 0.0136 \\
\hline Male sex & 1140/7992 (14.2) & $31 / 150(20.7)$ & 0.036 & $8142(100.0)$ & $\begin{array}{l}1.201(0.706 \text { to } \\
2.043)\end{array}$ & 0.4995 \\
\hline Caucasian ethnicity & $6462 / 7992(00.9)$ & $126 / 140(90.0)$ & 0.332 & $8142(100.0)$ & & \\
\hline Raynaud's phenomenon & $6904 / 7549(91.5)$ & $146 / 150 \mid 97.3)$ & 0.016 & $7699(94.6)$ & & \\
\hline Oesophageal symptoms & $4317 / 766(56.4)$ & $93 / 150(62.0)$ & 0.190 & $7811(95.9)$ & & \\
\hline Stomach symptoms & $1553 / 7337(21.2)$ & $49 / 150(32.7)$ & 0.008 & $7487(92.0)$ & & \\
\hline Intestinal symptoms & $1803 / 7587(23.8)$ & $63 / 150(42.0)$ & $<0.0001$ & $7737(95.0)$ & $\begin{array}{c}2.894(1.890 \text { to } \\
4.430)\end{array}$ & $<0.0001$ \\
\hline Scleroderma renal crisis & $123 / 7605(1.6)$ & $8 / 150(5.3)$ & 0.0015 & $7755(95.2)$ & $\begin{array}{c}1.489(0.525 \text { to } \\
4.219)\end{array}$ & 0.4540 \\
\hline Diffuse cutaneous subtype & 1990/7412(54.7) & $55 / 148(45.3)$ & 0.022 & 7560 (92.9) & $\begin{array}{l}0.825(0.525 \text { to } \\
1.296)\end{array}$ & 0.4033 \\
\hline Active digital ulcers ever & $2597 / 4973(52.2)$ & $66 / 126$ (52.3) & 0.97 & $5099(62.6)$ & & \\
\hline Joint synovitis & $734 / 7411(9.9)$ & 34/149(22.8) & $<0.0001$ & 7560 (92.9) & $\begin{array}{l}2.963(1.199 \text { to } \\
3.215)\end{array}$ & 0.0073 \\
\hline Joint contractures & $2191 / 7152(29.9)$ & $64 / 149(43.0)$ & 80.0001 & $7301(89.7)$ & & \\
\hline Tendon friction rubs & $404 / 7087(5.8)$ & $14 / 149(9.4)$ & $<0.0001$ & $7236(88.9)$ & & \\
\hline Muscle weakness & $1177 / 7512(15.7)$ & $59 / 148(39.9)$ & 80.0001 & $7650(94.1)$ & & \\
\hline Muscle atroph & $668 / 7334(9.1)$ & $37 / 148(25.0)$ & $<0.0001$ & $7482(91.9)$ & & \\
\hline CKelevation & 380/6259(6.1) & 47/140(33.6) & $<0.0001$ & $6399(7.6)$ & $\begin{array}{c}6.695(4.181 \text { to } \\
10.720)\end{array}$ & $<0.0001$ \\
\hline Conduction blocks & 880/5333(16.5) & $35 / 131(26.7)$ & 0.029 & $5464(67.1)$ & $\begin{array}{c}1.468(0.905 \text { to } \\
2.382)\end{array}$ & 0.1199 \\
\hline Elevated SPAP (ECHO) & $976 / 5592(17.5)$ & 19/137(13.9) & 0.33 & $5729(70.4)$ & & \\
\hline Lung fibrosis on plain X-rays & $64 / 117(54.7)$ & $1542 / 4527(51.6)$ & $<0.0001$ & $4644(57.0)$ & $\begin{array}{l}2.512(1.629 \text { to } \\
3.872)\end{array}$ & $<0.0001$ \\
\hline
\end{tabular}

Conclusions: In the largest series of anti-PM-Scl positive patients so far reported, well-known clinical associations were confirmed. Moreover, scleroderma renal crisis was more frequent than in the antibody-negative patient controls (which included a majority of anticentromere-positive patients, and a relatively small number of anti-RNA polymerase III-positive patients). However, this association was probably explained by covariates, such as joint and muscle involvement, or lung fibrosis. A possible role of corticosteroid therapy might therefore be suspected.

REFERENCE:

[1] Bruni C, et al. Rheumatology (Oxford). 2017;56:317-8.

Acknowledgements: Authors would like to thank the non-profit organisation 'Gruppo Italiano Lotta alla Sclerodermia' (GILS) for its substantial grant for this research project.

Disclosure of Interest: None declared

DOI: 10.1136/annrheumdis-2018-eular.4301

\section{THU0416 VERTEBRAL FRACTURE PREVALENCE AND MEASUREMENT OF THE SCANOGRAPHIC BONE ATTENUATION COEFFICIENT ON CT SCAN IN 70 PATIENTS WITH SYSTEMIC SCLERODERMA}

M. Fauny ${ }^{1}$, E. Bauer ${ }^{1}$, E. Albuisson ${ }^{2}$, J. Perrier-cornet ${ }^{1}$, J. Deibener ${ }^{2}$, F. Chabot ${ }^{2}$, D. Mandry ${ }^{2}$, O. Huttin ${ }^{2}$, I. Chary-valckenaere ${ }^{1}$, D. Loeuille ${ }^{1} .{ }^{1}$ Rheumatology; ${ }^{2} \mathrm{CHU}$ Nancy, Vandoeuvre Les Nancy, France

Background: Osteoporosis screening is not systematic in sclerodermic patients but some studies demonstrated a similar risk between rheumatoid arthritis and systemic scleroderma. ${ }^{1,2,3}$ Thoracic and/or TAP (thoraco-abdomino-pelvic) CT (Computed Tomography) scans are classically performed in the follow-up of scleroderma, mainly to evaluate lung involvement.

Objectives: To study vertebral fracture (VF) prevalence and the scanographic bone attenuation coefficient of the first lumbar vertebra (SBAC-L1) on CT scans in systemic scleroderma patients. Secondary objectives are to study specific risk factors of SBAC-L1 $\leq 145$ Hounsfield Units (HU) and to evaluate SBAC-L1 measurements reliability.

Methods: This monocentric retrospective study included patients followed from 2000 to 2014 and fulfilling ACR/EULAR 2013 criteria for systemic scleroderma and who underwent a thoracic or TAP CT scan. Osteoporotic risk factors, Dual Energy X-ray Absorptiometry (DXA) measurements and clinical characteristics were collected. For CT scan, the VFs were determined according to Genant's classification on sagittal sections. The SBAC-L1 was measured in Hounsfield Units $(\mathrm{HU})$ on axial section of $\mathrm{L} 1$ in a Region of Interest drawed in trabecular bone. Intra- and inter-reader reliabilities for SBAC-L1 were calculated. An SBAC $\mathrm{L} 1 \leq 145 \mathrm{HU}$ (fracture threshold) was used to define patients at risk of VF. ${ }^{4}$ Predictive factors for VF or SBAC-L1 $\leq 145 \mathrm{HU}$ were studied.

Results: A total of 70 patients were included (mean age: $62.3( \pm 15.6)$ years, women $88.5 \%$, diffuse scleroderma $22.9 \%(n=16))$ in the study. Sixty patients $(85.7 \%)$ presented with at least one clinical risk factor for osteoporosis. Eighteen patients $(25.7 \%)$ received vitaminocalcic supplementation and $10(14.3 \%)$ received antiresorptive therapy. DXA was only performed on 30 patients $(42.8 \%)$ and $5(16.7 \%)$ of them presented a T-score $\leq-2.5$ DS. 3 VFs were detected in 3 patients $(4.3 \%)$. The mean SBAC-L1 was $157.26 \mathrm{HU}( \pm 52.1)$, and 35 patients (50\%) presented a SBAC-L1 $\leq 145 \mathrm{HU}$. SBAC-L1 measurements were highly reliable (Kappa $>0.9$ for both intra- and inter-reader reliability). For the univariate analysis, a SBAC-L1 $\leq 145 \mathrm{HU}$ was significantly associated with age (OR=1.09, C 95\%: 1.04-1.13), calcinosis (OR=6.3, $\mathrm{Cl} 95 \%: 1.61-24.75)$ and periarticular calcifications $(\mathrm{OR}=3.22, \mathrm{Cl} 95 \%$ : 1.06-9.77). For the multivariate analysis, age (especially patients older than 63 years), calcinosis and acro-osteolysis were independently associated with a SBAC-L1 $\leq 145 \mathrm{HU}$.

Conclusions: On a large sample of sclerodermic patients with clinical risks of osteoporosis, only $42.8 \%$ were screened for DXA and $16.7 \%$ of them were osteoporotic. The VF prevalence on CT scan was $4.3 \%$ and the SBAC-L1 measurement identified $50 \%$ of the population at the fracture threshold. The presence of calcinosis, periarticular calcifications or acro-osteolysis should lead to an osteoporosis screening, especially for patients under 63 years old.

\section{REFERENCES:}

[1] Avouac J. Arthritis Care Res (Hoboken). 2012 Dec;64(12):1871-8.

[2] Yuen SY. J Rheumatol. 2008 June;35(6):1073-8.

[3] Kilic G. Int J Rheum Dis 1 avr 2016;19(4):405-11.

[4] Pickhardt PJ. Ann Intern Med 2013;158(8):588-95.

Disclosure of Interest: None declared

DOI: 10.1136/annrheumdis-2018-eular.1501

\section{THU0417 WHOLE BODY DISTRIBUTION AND CLINICAL ASSOCIATIONS OF TELANGIECTASIA IN SYSTEMIC SCLEROSIS: A CROSS-SECTIONAL STUDY}

M. Jouvray ${ }^{1}$, D. Launay ${ }^{1}$, S. Dubucquoi ${ }^{2}$, V. Sobanski ${ }^{1}$, C. Podevin ${ }^{3}$, M. Lambert $^{1}$, S. Morell-Dubois ${ }^{1}$, H. Maillard ${ }^{1}$, P.-Y. Hatron ${ }^{1}$, E. Hachulla ${ }^{1}$, J. Giovannelli ${ }^{3}$.

${ }^{1}$ département de médecine interne et immunologie clinique; ${ }^{2}$ Institut d'Immunologie: ${ }^{3}$ Centre de Référence des Maladies Autoimmunes et Systémiques Rares du Nord et Nord-Ouest de France (CeRAINO), CHU Lille, Lille, France

Background: Telangiectasia (TA), one of the diagnostic criteria for systemic sclerosis (SSc), could be a clinical marker for the severity of vasculopathy, including pulmonary hypertension $(\mathrm{PH})$.

Objectives: We designed a cross-sectional study: (i) to describe the whole-body distribution of TA, (ii) to assess the associations between the whole-body number of TA and the characteristics of patients, (iii) to determine whether the number of TA may be useful to discriminate SSc-PH patients.

Methods: Patients were included in the National Referral Centre for Rare Systemic And Autoimmune Diseases if they fulfilled the 2013 ACR/EULAR criteria for SSc. They were excluded if they had received laser treatment. The whole-body number and distribution of TA were recorded at inclusion. The associations were studied using univariate, adjusted and multiple linear regressions.

Results: 106 patients were enrolled, including 12 with $\mathrm{PH}$. The median (interquartile range) number of TA was 30 (82.7). Their distribution was: $37.2 \%$ on the face, $33.2 \%$ on the upper limbs including $26.4 \%$ on the hands, $28.1 \%$ on the trunk including $17.1 \%$ for the upper part of the trunk, and $1.5 \%$ on the lower limbs. Using multivariate linear regression model, the whole-body telangiectasia number was independently associated with male gender (percentage change $(95 \% \mathrm{Cl})=$ $+144.4 \%(7.5 ; 455.9), p=0.033)$, pulmonary hypertension $(+162.8 \%(5.6 ; 553.8)$ $\mathrm{p}=0.038)$, history of pulmonary embolism $(+336.4 \%(39.0 ; 1270.1), p=0.012)$, glomerular filtration rate $\left(-1.6 \%(-3.2 ;-0.1)\right.$ per $1 \mathrm{ml} / \mathrm{mn} / 1.73 \mathrm{~m}^{2}$ increase, $\left.p=0.038\right)$ and soluble endoglin $(+28.2 \%(1.2 ; 62.5)$ per $1 \mathrm{ng} / \mathrm{ml}$ increase, $\mathrm{p}=0.039)$. The $\mathrm{ROC}$ analyses assessing the ability of telangiectasia to discriminate the presence of pulmonary hypertension revealed that the area under the curve was significant for the telangiectasia number on the whole body $(0.77(0.57 ; 0.88))$, on the hands and face $(0.81(0.57 ; 0.91))$ and on the hands $(0.77(0.57 ; 0.89))$. 